Leading the tributes to editor
John Maddox

SIR — In April 1974, some months after I had taken over from John Maddox as editor of Nature, I was driving home from the printers with a colleague at four in the morning, having just put the latest issue to bed. News came in over the radio of a coup in Portugal. What would John have done? We agreed that he would have turned the car round and written a new thousand-word Editorial: 'What future for Portuguese science? The coup in Lisbon is, or ought to be, an opportunity for Portuguese scientists...' We smiled at the thought, but drove on.

This little story exemplifies John's approach to Nature. As a one-time journalist, he prized immediacy. He had a formidable list of contacts, and even if he hadn't known any Portuguese scientists, he would still have created a sense of authority.

Until his arrival as editor in 1966, Nature had been a worthy journal of record but lacking in flair; it changed rapidly as John brought his journalistic background to bear. 'We wuz robbed' was the title of an Editorial written at the time of the 1966 Football World Cup, proposing a new method for determining the winner. Very different from previous fare, which ran along the lines of 'comment on the progress of Her Majesty's Alkali Inspectorate as described in its 47th Annual Report'.

John gathered around him enthusiasts in the academic world for this new style of journal. He urged us to seek out good scientific papers and gave us free rein to hold forth in Editorials. We were awed by his restless energy in generating thousands of words.

John was immensely active. He took on broader responsibilities within Macmillan; he launched the weekly Nature New Biology and Nature Physical Science; he spoke regularly on the radio; he challenged environmentalists' excesses and wrote a book,
Doomsday Syndrome (Macmillan, 1972). That year, he founded Maddox Editorial Ltd, which went on to publish a European journal. The result of all this was that Nature received less than his fulltime attention and began to fray at the edges. In 1973, Macmillan and John parted company.

Shortly before I took over, John expounded his 'diminishing tenure' rule to me by drawing a little graph of duration of successive Nature editorships. Norman Lockyer, the first, served for a remarkable 50 years, but the stints of his successors - Richard Gregory, joint editors Jack Brimble and Arthur Gale, and John himself became steadily shorter. In his impish way, John, who had been editor for seven years, predicted I'd last three-and-a-half.

Fortunately I managed rather longer, but when John, by then director of the Nuffield Foundation, got wind of my interest in moving on, he invited me to lunch and revealed that he very much wanted to get back into the editor's chair. Out came the imp in him again: 'Why don't we swap jobs?'

He returned in 1980; at that time, many doubted his wisdom in going back. He proved us wrong over the next 15 years and spectacularly disproved the 'diminishing tenure' rule.

David Davies Cross Keys House, Fovant, Salisbury SP35JH, UK

The Nature John Maddox special is at http://tinyurl.com/dm6p7s

\section{Water: conflicts set to arise within as well as between states}

SIR - In her Essay 'Do nations go to war over water?' (Nature 458, 282-283; 2009), Wendy Barnaby quotes from my 1995 speech in Stockholm, in which I said "The wars of this century have been on oil, and the wars of the next century will be on water ... unless we change the way we manage water". The opening part was picked up by the media as a sound bite that was nevertheless valuable in pushing water issues up towards the top of the agenda, although the caveat, the operative part, was largely overlooked.

However, I do not consider that to be alarmist. I know all the arguments that have been made by others about international wars being unlikely for water, and they are probably right. But civil strife between competing groups within countries over water rights are very serious. Many of the wars of the past 20 years, on issues other than water, have been between groups within one sovereign state. That did not make them any less murderous.

Furthermore, the century is just starting and we have not seen the full range of expected environmental, demographic and political challenges unfold. Water in this century will become a major source of strife between groups within countries. Drought has driven many tribes in Africa into terrain that they are not normally expected to occupy. When coupled with other factors such as ethnic or religious divides, this becomes a dangerous mix.

Water may also become a casus belli between states, if the downstream nation is considerably stronger militarily than the one upstream, and the latter tries to block or reduce the flow of water. Whether it is acted on or not depends on many other issues, including the nature of the relationships between the countries concerned.

Solutions will require actions on many fronts, including in many other sectors with which water interacts economically and environmentally. But much also remains to be done to improve our resource management in the water sector broadly defined: water for food, industry, energy, domestic and municipal use, and for the environment.

The answer to the clarion call of 1995 to avoid 'water wars' is to manage our water resources better, learning from past experience, generalizing best practices and facing up to the mounting challenges that are coming our way, not to dismiss the issue as a myth. Ismail Serageldin Library of Alexandria, Shatby 21526, Alexandria, Egypt e-mail: is@bibalex.org

\section{Water: resistance on the route towards a fair share for all}

SIR - Wendy Barnaby's Essay 'Do nations go to war over water?' (Nature 458, 282-283; 2009) is a welcome counter to mainstream media hype about conflicts over water. But all is not quiet on the waterfront, and the need to establish fair water-sharing is growing increasingly urgent.

For example, southern Iraqi farmers downstream of dams located on the Tigris River in Iraq, Syria and Turkey are being forced into urban centres as the reduced river flows become overwhelmed by sea water. Palestinian farmers eke out a living dependent on highly variable and scarce rainfall, next door to the industrial farms of Israeli settlers whose irrigation water is state-subsidized. The flood-and-drought cycles of the Ganges inundate farmers in downstream Bangladesh.

Attempts to reconcile the mockery that this fluid resource makes of political borders are well under way. The movement to establish fair water-sharing principles is gaining momentum among legal bodies and nongovernmental organizations. Although the UK government is resisting calls to ratify the 1997 United Nations Watercourses Convention, demographic and anticipated climate-change pressures dilute its excuses.

Water conflicts (not wars) are a clear and present danger for millions. They deserve our full collective scientific, financial and diplomatic attention.

Mark Zeitoun School of International Development, University of East Anglia, Norwich NR4 7TJ, UK e-mail:m.zeitoun@uea.ac.uk 